3 Martens J, Demedes M, Vanmeenen MT, Dequeker J. Respiratory muscle dysfunction in systemic lupus erythematosus. Chest 1983;84:170-5.

4 Segal AM, Calabrese LH, Ahmad M, Tubbs RR, White CS. The pulmonary manifestations of systemic lupus erythematosus. Semin Arthritis Rheum 1985;14:202-24.

5 Reynolds HY. Bronchoalveolar lavage. Am Rev Respir Dis 1987;135:250-63.

6 Shenberger KN, Schned AR, Taylor TH. Rheumatoid disease and bronchogenic carcinoma-case report and review of the literature. $\mathcal{F}$ Rheumatol 1984;11:226-8.

7 Stack BHR, Grant IWB. Rheumatoid interstitial lung disease. Brf Dis Chest 1965;59:202-11.

\section{Reye's syndrome: assessment of intracranial} monitoring

SIR,-We agree with Dr J G Jenkins and colleagues ( 7 February, $p$ 337) that the maintenance of an adequate cerebral perfusion pressure is important in managing patients with Reye's syndrome, but this may not be the only factor determining outcome, as a recent case shows.

A 7 year old girl was admitted as a precaution shortly after her 4 year old brother developed Reye's syndrome. She was well on admission, but her clinical condition deteriorated rapidly, and within four hours she was unconscious. Reye's syndrome was diagnosed (table), and early intensive management was started, but she deteriorated further to Lovejoy stage 4. Though her intracranial pressure was not raised when a Ladd epidural monitor was inserted, she subsequently had several sustained rises in pressure with peaks $>50 \mathrm{~mm} \mathrm{Hg}$. On at least two occasions her cerebral perfusion pressure fell below $25 \mathrm{~mm} \mathrm{Hg}$ for periods of more than an hour. Though continuous electroencephalographic monitoring showed seizure activity and many adverse features, full intensive care was not withdrawn as her brain stem auditory evoked potentials were normal. Active treatment for raised intracranial pressure was needed for 21 days, and she was eventually weaned off the ventilator on day 28 . She was discharged on day 59 , and at review nearly a year later she had no neurological deficit and had returned to school and full activities.

In the series reported by Dr Jenkins and coworkers all 10 patients with a cerebral perfusion pressure $<40 \mathrm{~mm} \mathrm{Hg}$ either died or sustained severe neurological handicap. In spite of her cerebral perfusion pressure falling to $<40 \mathrm{~mm} \mathrm{Hg}$ our patient recovered. We suggest that this might be because our patient was treated very early as she had been admitted as a precaution after the onset of Reye's syndrome in her brother. Delay in diagnosis of Reye's syndrome is commonly associated with a poor outcome, particularly in patients with rapidly advancing coma. ${ }^{1}$ Other reviewers have suggested that the likelihood of recovery is related to the stage of the illness at which intensive management or raised intracranial pressure is started. ${ }^{2}$

Our case illustrates, firstly, the need for a high index of suspicion for siblings of children with Reye's syndrome and, secondly, that even in a case

Biochemical details of patient with Reye's syndrome

\begin{tabular}{lccc}
\hline & $\begin{array}{c}\text { On } \\
\text { admission }\end{array}$ & Maximum & $\begin{array}{c}\text { Normal } \\
\text { range }\end{array}$ \\
\hline $\begin{array}{c}\text { Alanine transaminase } \\
\text { activity (IU/I) } \\
\text { Aspartate transaminase } \\
\text { activity (IU/I) }\end{array}$ & 1215 & 1215 & $0-45$ \\
$\begin{array}{c}\text { Ammonia concentration } \\
\text { (mmol/) }\end{array}$ & 25 & 690 & $6-51$ \\
$\begin{array}{c}\text { Prothrombin time } \\
\text { (index/control) } \\
\text { Blood glucose concen- } \\
\text { tration (mmol/) }\end{array}$ & $18 / 13$ & $19 / 13$ & \\
Bilirubin concentration \\
(mmol/)
\end{tabular}

of rapidly progressing coma with profound reduction in cerebral perfusion pressure a ful functional recovery is still possible.

A M EMOND

P J FLEMING

Bristol Maternity Hospital,

Bristol BS2 8EG

Dezateux CA, Dinwiddie R, Helms P, et al. Recognition and early management of Reye's syndrome. Arch Dis Child 1986;61:647-51.

2 De Vivo DC. Reye's syndrome. Neurologic Clinics (Philadelphia) 1985;3:95-115.

\section{Dangers in treating hyponatraemia}

SIR,-Professor J D Swales (31 January, p 261) seems to support the recommendation of Stern et al that hypernatraemia should not be corrected by more than $12 \mathrm{mmol} /$ day. ${ }^{1}$ We consider this advice to be too cautious, particularly in patients with acute hyponatraemia. In addition, we find hypertonic, not isotonic, sodium to be effective, as the following two cases illustrate.

Case 1-A 73 year old man became confused, restless, and disorientated after transurethera prostatectomy. He was hypotensive, in respiratory distress, and anuric. Massive absorption of the irrigating $1.5 \%$ glycine caused the transurethral reaction syndrome. He was thought to be hypovolaemic and a further 2 units of blood and 4 litres of isotonic solution were given. After 24 hours he went into coma, with fixed dilated pupils; his blood pressure fell to $80 / 40 \mathrm{~mm} \mathrm{Hg}$, his pulse to 30 beats $/ \mathrm{min}$, and his central venous pressure to $1 \mathrm{~cm} \mathrm{H} \mathrm{H}_{2} \mathrm{O}$. The amoun of sodium required to raise serum osmolarity was calculated, ${ }^{23}$ and $500 \mathrm{ml} 5 \%$ sodium chloride was given in one hour, then repeated. He regained consciousness during the infusion and passed 5 litres of urine. He made a full recovery.

Case 2-A woman aged 74 was admitted with myocardial infarction confirmed by raised cardiac enzyme activities. She had been receiving nifedipine and Moduretic, which were withdrawn as she became persistently hypotensive $(90 / 50 \mathrm{~mm} \mathrm{Hg})$. She suffered a cardiac arrest on the sixth day. Two days later she became confused and had visual hallucinations. She had been receiving 2.5 litres $5 \%$ glucose intravenously daily, but her urine output was gradually declining. A normal sarum sodium concentration of $140 \mathrm{mmol} / \mathrm{l}$ on admission dropped to $114 \mathrm{mmol} / 1$, and osmolality fell to $241 \mathrm{mmol} / \mathrm{kg}$ over eight days. Treatment with fluid restriction and frusemide $160 \mathrm{mg}$ for two days was ineffective. She continued to deteriorate; serum sodium concentration dropped to $108 \mathrm{mmol} / \mathrm{l}$ and osmolality to $236 \mathrm{mmol} / \mathrm{kg}$, with urine osmolality of $294 \mathrm{mmol} / \mathrm{kg}$ and undetectable sodium. She underwent an infusion of $500 \mathrm{ml} 1 \cdot 8 \%$ sodium chloride ove four hours, which raised her serum sodium concentration to $122 \mathrm{mmol} / \mathrm{l}$. A further dose given over the next eight hours raised the serum sodium concentration to $132 \mathrm{mmol} / \mathrm{l}$ and osmolality to $294 \mathrm{mmol} / \mathrm{kg}$. She passed 3 litres of urine, and her neurological signs disappeared. She made a full recovery.

These cases are anecdotal but provide useful guidance. Any clearly definable, acute reduction in serum sodium concentration ( $>20 \mathrm{mmol} / \mathrm{l}$ ) associated with severe neurological signs should be corrected rapidly. Hypertonic sodium relieves brain oedema and induces diuresis when given early and in a concentration that corrects osmolality without aggravating volume overload..$^{23}$ Rapid correction may be dangerous in patients with chronic hyponatraemia in whom osmotic adaptation has occurred. A delay in treating acute hyponatraemia, however, may result in permanent damage of the oedematous brain. An isotonic solution can also be dangerous as it achieves little osmotic correction and worsens volume overload. ${ }^{3}$

We conclude that acute hyponatraemia of iatrogenic origin, such as the transurethral reaction syndrome $^{2}$ and medical and postsurgical syndromes, ${ }^{3-5}$ necessitates immediate action. Hyper- onic sodium is livesaving and deserves scientific evaluation.

J A WOJTULEWSKI M D PENNY

Eastbourne District General Hospital,

East Sussex BN21 2UD

Sterns RH, Riggs JE, Schochet SS. Osmotic demyelination syndrome following correction of hyponatremia. $N$ Engl $\mathcal{f}$ Med 1986;314:1535-42.

2 Harrison RH, Boren JS, Robinson JR. Dilutional hyponatremic shock: another concept of the transurethral prostatic reaction. f Urol 1956;75:95-110.

3 Worthley LIG, Thomas PD. The treatment of hyponatraemic seizures with intravenous $29 \cdot 2 \%$ saline. $\mathrm{Br} \mathrm{Med} \mathcal{F}$ 1986;292: 168-70.

4 Thompson PD, Gledhill RF, Quinn. NP, et al. Neurological complications associated with parenteral treatment: central pontine myelinolysis and Wernicke's encephalopathy. $\mathrm{Br}$ pontine myelinolysis and
Med f 1986;292:684-5.

5 Dandona P, Fonseca V, Baron DN. Hypoalbuminaemic hyponatraemia: a new syndrome? BrMed $\mathcal{J}$ 1985;291:1253-5.

AUTHOR'S REPLY,-There are already numerous case reports presenting conflicting evidence for or against the safety of rapid correction of hyponatraemia. ${ }^{1-3}$ Though I agree that anecdotal evidence may be helpful when controlled trials are difficult, there are also grave dangers in using very selected case reports as a basis for general advice. Even in the study by Sterns $e t$ al, which reported on a consecutive group of patients, neurological damage was observed in only a minority of the patients (five out of 43) when hyponatraemia was corrected rapidly. ${ }^{3}$ The absence of neurological damage in two isolated cases is not particularly persuasive in such circumstances. Apparent improvement caused by a rise in serum sodium concentration must be distinguished from spontaneous recovery and the effects of volume expansion in a sodium and fluid depleted patient; the second patient described by $\mathrm{Mr}$ Ghanem and coworkers, who had been exposed to large doses of diuretics and water restriction, may well have benefited from such volume effects. It may be possible to obtain a clearer picture with experimental hyponatraemia induced by three days of vasopressin treatment in rats. In one study rapid correction of hypertonic saline produced pontine demyelination. ${ }^{4}$

Rapid rises in serum sodium concentration may not be harmful in the correction of acute hyponatraemia that may occur, for example, postoperatively: osmotic shifts between intracellular and extracellular fluid may then not have had time to occur. Interestingly, in the review reported by Sterns et al most of the reports of neurological sequelae associated with rapid correction occurred in hyponatraemia induced by diuretics, which was presumably fairly chronic. The most important lesson in such reports (and of the first case reported by $\mathrm{Mr}$ Ghanem and colleagues), however, is surely that postoperative water intoxication caused by infusion or absorption of sodium free fluids should be prevented. The dangers of such mishaps are well recognised and may be irreversible whatever corrective regimen is used.

J D SWALES

Department of Medicine,

Leicester Royal Infirmary,

Leicester LE2 7LX

1 Ayus JC, Olivero JJ, Frommer JP. Rapid correction of severe hyponatremia with intravenous hypertonic saline solution. Am $f$ Med 1982;72:43-8.

2 Arieff AI. Hyponatremia, convulsions, respiratory arrest and permanent brain damage after elective surgery in healthy women. N Engl f Med 1986;314:1529-35.

3 Sterns RH, Riggs JE, Schochet SS. Osmotic demyelinatio syndrome following correction of hyponatremia. N Engl $\mathfrak{f}$ Med 1986;314:1535-42.

4 de Masters BKK, Norenberg MD. Rapid correction of hyponatraemia causes demyelination relative to central pontine myelinolysis. Science 1987;211:1068-70. 